\title{
Effect of Financial Development on the Transmission of Monetary Policy
}

\author{
Rama Seth*, Vaanchitha Kalyanaraman \\ Department of Finance and Control, Indian Institute of Management Calcutta, Kolkata, India \\ Email: *rama_seth@iimcal.ac.in, vaanchithak15@email.iimcal.ac.in
}

How to cite this paper: Seth, R. and Kalyanaraman, V. (2017) Effect of Financial Development on the Transmission of Monetary Policy. Theoretical Economics Letters, 7, 795-813.

https://doi.org/10.4236/tel.2017.74058

Received: May 2, 2017

Accepted: June 11, 2017

Published: June 14, 2017

Copyright (C) 2017 by authors and Scientific Research Publishing Inc. This work is licensed under the Creative Commons Attribution International License (CC BY 4.0).

http://creativecommons.org/licenses/by/4.0/

\section{(c) (i) Open Access}

\begin{abstract}
This paper looks at the effect of financial development on output and bank liquidity by doing a cross-country analysis of 119 countries across 18 years from 1997-2014. We develop three hypotheses by combining multiple strands of literature which have heretofore existed in parallel. The main research question is whether financial development serves to provide greater bank liquidity and whether it does indeed stimulate output growth. This question is of particular relevance when there are changes in monetary policy. This paper goes to the heart of examining whether monetary policy is transmitted more effectively with better financial development and whether the goal to achieve output changes via monetary policy is better effected in an environment of developed financial markets. Our results support the hypotheses that financial development positively impacts output, and negatively affects bank liquidity. We also show that with financial development, the effect of bank liquidity on output is heightened.
\end{abstract}

\section{Keywords}

Monetary Policy, Financial Development, Money Supply, Bank Liquidity, Output

\section{Introduction}

Banks are a unique kind of financial institution. The modern theory of financial intermediation says that banks are different from other financial institutions because of their ability to reduce the information asymmetry between borrowers and depositors (Leland and Pyle [1], Diamond [2] and Ramakrishnan and Thakor [3]). According to this theory, there are two central roles of banks: creating liquidity and transforming risk (Berger and Bouwman [4]).

Some of the earliest papers which talk about the importance of liquidity creation as a central function of banks are Bryant [5] and Diamond and Dybvig [6]. 
Liquidity creation is done by offering deposits which are more liquid than the assets banks hold. In this way, investors would prefer to invest in a bank rather than holding illiquid assets directly. Banks then create liquidity by financing comparatively illiquid assets with liquid liabilities (Berger and Bouwman [4]). When banks create deposits that are more liquid than the assets that they hold, an insurance system develops where all depositors share the risk of liquidating an asset at a loss early (Diamond [7]). Liquidity can be created off balance sheet also with the help of loan commitments or other liquid funds (Kashyap, Rajanand Stein [8] and Holmstrom and Tirole [9]). A simple way to understand liquidity creation is that it is based on the fact that banks are simultaneously able to provide illiquid loans to borrowers while also having enough reserves to ensure that depositors are able to withdraw funds at par value whenever they want.

Monetary policy has long been the instrument used to control supply of money in an economy. It is used to keep inflation in check manage optimal growth of output in the country (Friedman [10]). The instrument is used by controlling the amount of liquidity that is available.

Prior literature has noted that financial development is very important to the economic growth of the country. There were initially some debates as to whether financial development drives economic output or if there is a feedback loop such that increased economic output causes financial development. It has been observed that more financially developed countries also grow faster and the interesting thing is that the effect is causal, meaning that financial development is not just occurring because of economic growth, and it also causes economic growth (Demirgüç-Kunt and Levine [11] and Levine [12]). Because of this, we want to see what the effect of different levels of financial development is on bank liquidity and output.

Monetary policy which is used to control the economy has different degrees of effectiveness in the economies with varying levels of financial development. In this paper, we examine first how the level of financial development of a country impacts on the monetary policy on bank liquidity and output -these can be thought of as the intermediate target and target of central bank policy. Second, the paper examines how financial development affects the impact of liquidity creation on the total economic output of the country.

The unique aspect of this paper is that it brings together a few different strands of literature and examines these relationships across cross countries. There are papers with look at the effect of financial development on monetary policy transmission (Carranza, Galdon-Sanchezand Gomez-Biscarri [13]) and also papers which look at how changes in monetary policy affect output and bank liquidity (Sims [14], Uhlig [15], Bernanke and Gertler [16] and Kashyap and Stein [17]), which is sets the stage for our first two hypotheses. However, there are no papers which tie together these two strands of literature and test how effective monetary policy is in changing bank liquidity and the output at different stages of financial development. This test is at the heart of our third hypothesis. There have been papers which look at the effect of financial devel- 
opment on output (Bencivenga and Smith [18] and Greenwood and Jovanovic [19]) and also ones which look at the relationship between bank liquidity and economic output in a nation (Jayaratne and Strahan [20], Smith [21] and Fungácová, Hasan and Weill [22]). Again here, he aims to tie the two different strands of literature to find out the effect.

The research question that we want to look at is how does financial development affect a) the impact of monetary policy on output, b) the impact of monetary policy on bank liquidity, and c) the impact of bank liquidity on output.

\section{Literature Review and Hypothesis Development}

Previous literature has not found support for a strong relationship between monetary policy effectiveness and financial development of a country. One the one hand we could argue that financial development reduces the effectiveness of monetary policy. Financial innovation results in the creation of new instruments. With the help of these new instruments, banks are able to insure themselves against unexpected changes in monetary policy (Carranza, Galdon-Sanchezand Gomez-Biscarri [13]). This insurance could impede the effectiveness of monetary policy.

The availability of derivatives for example, introduces leakages into the transmission of monetary policy. Consider one aspect of financial developmentthe availability of financial instruments. In a relatively underdeveloped financial environment as in India, instruments available to hedge risks are fewer as compared to a relatively developed market like the US. The size of the derivatives market is much bigger in the US compared to India and the instruments used in the US are much more complex and also greater in volume. In India banks are less likely than US banks to be able to hedge against certain risks.

On the other hand financially less developed countries are not able to transmit monetary policy effectively. This handicap arises because in countries where the financial system is not very well developed, there are many more cash leakages from the system. These leakages weaken the multiplier effect. Due to this effect, changes in monetary policy could take much longer to transmit into the rest of the economy (Carranza, Galdon-Sanchezand Gomez-Biscarri [13]). This factor is potentially more debilitating for less developed countries that are anyway capital constrained.

One measure of the effectiveness of monetary policy is its impact on output in the economy. For countries that are less financially developed, sources of funds are not many or diverse, and reliance on bank funds means that cash leakages, would result in monetary policy having a potentially weaker impact on output. The above two effects suggests that the relationship between financial development and monetary policy effectiveness is ambiguous. It is difficult to say whether financial development will improve or reduce the impact on output.

In what follows we will discuss effects from the perspective of monetary policy loosening (henceforth referred to as MPL as used by Berger and Bouwman [23]). We will assume symmetry i.e. when there is monetary policy tightening, the op- 
posite effect will take place. This assumption has been made previously in the literature (Berger and Bouwman [23]).

The direction of the effect of monetary policy on the output has been widely researched. Both empirics and theory have been used to show that a loosening of monetary policy enables growth in the GDP or output (Sims [14] and Uhlig [15]).

From the above discussion, we arrive at our first bi directional hypothesis.

Hypothesis 1a: Financial development positively affects the impact of monetary policy on output.

Hypothesis 1b: Financial development negatively affects the impact of monetary policy on output.

MPL is expected to increase the liquidity of banks both in the form of loans and deposits through the bank lending channel (Kashyap and Stein [17] and Bernanke and Gertler). By increasing bank reserves, MPL increases bank deposits. This increase in deposits results in one or both of the following: (1) an increase in the amount of loanable funds available resulting in a lower cost of capital to production centers and (2) intermediaries getting cheaper deposits instead of having to borrow from expensive federal funds or CDs (Bernanke and Blinder [24] and Stein [25]). As more loanable funds become available there is also a reduction in credit rationing among the customers (Stiglitz and Weiss [26]), so loanable funds are more widely dispersed in the economy.

The above discussion begs the question of whether financial development dilutes or intensifies the impact of monetary policy on bank liquidity. Again here there could be two opposing effects. On the one hand, developed economies with well-developed formal and easily accessible markets in place will be able to support smoother churning of liquidity in the economy. Fewer leakages occur with a robust and reliable banking system. Loanable funds borrowed from banks will find their way back into deposits thereby causing a multiplier effect on bank liquidity. The strength of this multiplier will depend on the level of financial development of the country. Take for example an American business that borrows from a bank. Accounts paid such as those of employees, vendor's dues, etc. find their way back into the banking system with very few leakages owing to the largely cashless nature of transactions. In India which we consider to be relatively underdeveloped, the same process is likely to have many more leakages owing to the relatively larger reliance on cash transactions, not all of which come back into the banking system, owing to much lower financial inclusion.

On the other hand, due to the presence of several alternative sources of funds in financially developed economies, the multiplier effect may be weakened owing to use of instruments outside the banking system. In a country with high levels of financial development, there are various investment vehicles that are well regulated with good governance, other than bank deposits. Examples are welldeveloped, transparent and well regulated secondary markets for equities and even bonds that are higher income earning than bank deposits with not too much additional risk. It is therefore not necessary that people put the money 
back into the banking system. While this may not affect the output of the country, it will likely affect bank liquidity. Even when borrowing is from banks, these loanable funds may not be invested right back into banks owing to alternative investment vehicles. Hence the multiplier may not work its magic on bank liquidity.

The above discussion leads us to propose the second bi directional hypothesis which will be tested using interaction terms (Figure 1):

Hypothesis 2a: Financial development increases the impact of monetary policy on bank liquidity.

Hypothesis 2b: Financial development dilutes the impact of monetary policy on bank liquidity.

There are a few papers which look at the financial impact of finance on the output of the economy (Greenwood and Jovanovic [19], Bencivenga and Smith [18], Ross, Levine and Zervos [27] and Ross and Levine [28]) but we are specifically more interested in how financial development is affecting output when bank liquidity is taken into consideration. In less financially developed countries, bank liquidity is the major source of investment and growth because access to other sources of funds is limited. Due to this limitation, bank loans become the major source of economic growth for the country (Smith [21] and Jayaratne and Strahan [20]). Money has been shown in the literature to have a causal effect on output ( $\mathrm{Wu}$ and $\mathrm{Ni}[29]$ ). Deposits are an important part of liquidity creation, and the availability of liquidity is very important for the economy to be stable and not be hit by a financial crisis (Kashyap Rajan and Stein [8]).

Off balance sheet guarantees are also very important as they help companies plan their investment and manage their risk. Usually, these guarantees are used as a backup for other capital market financing like $\mathrm{CP}$ and municipal revenue bonds, and so they help with economic growth (Berger and Sedunov [30]). Also, derivatives and other specialized instruments which are mainly used off-balance

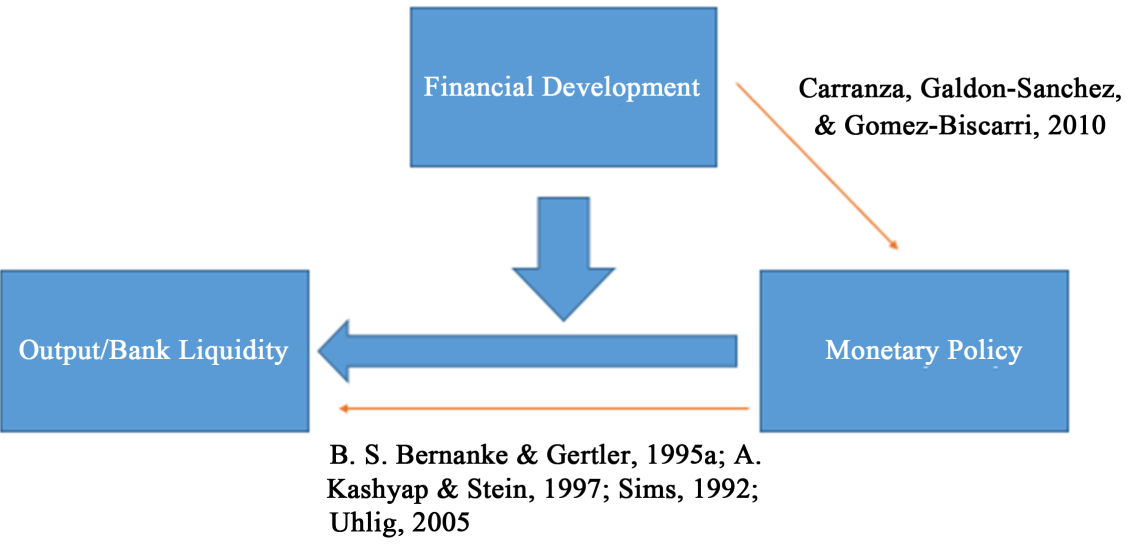

Figure 1. Diagram for Hypothesis 1 and 2. The blue diagram refers our research question while the orange lines with authors show the prior research that has been done. We look at the effect of financial development on output and bank liquidity in the presence of monetary policy changes. We are interested in the interaction between financial development and monetary policy. 
sheet help the economy by allowing companies to hedge their risk from changing interest rates, foreign exchange rates, etc. (Stulz [31]). The availability of loans is especially important as it propagates through the bank lending channel. Specifically small banks cater to SMEs which form an essential part of the economy (Kashyap and Stein [32] and Berger and Bouwman).

The other side of the story is that while banks provide a much-needed source of money to the economy, the fundamental thing that is important is the trust in banks. Unless a person trusts the bank, he is neither going to deposit not going to withdraw money in the form of loans from banks. Hence there is no increase in credit in the economy when people distrust banks (Keho [33]). There are many factors which affect the trust in banks. One cross-country study by (Fungácová, Hasanandand Weill [22]) shows that trust banks increases with income, and with enhanced access to television. Countries which are on the lower spectrum of financial development suffer from lower levels of income in general, so many persons are much more comfortable dealing in cash and never depositing anything in the bank. Similarly, in countries which are not highly developed we also have a lack of complete financial penetration where many persons are not able to access banks despite wanting to. Hence a possible outcome in countries with lower financial development is that an increase in bank liquidity will not necessarily help improve the GDP of the country. In fact, if money is made available at the bank level in a developed nation vs. a nation that is not developed, the nation with better development will produce more output in terms of GDP as more people will take the loan and also put money back into the system.

Hence here we believe that the interaction term between the bank liquidity and financial development will be able to tell us which theory holds true. This also leads us to our third bi directional hypothesis (Figure 2).

Hypothesis 3a: Financial development positively affects the impact of bank liquidity on output.

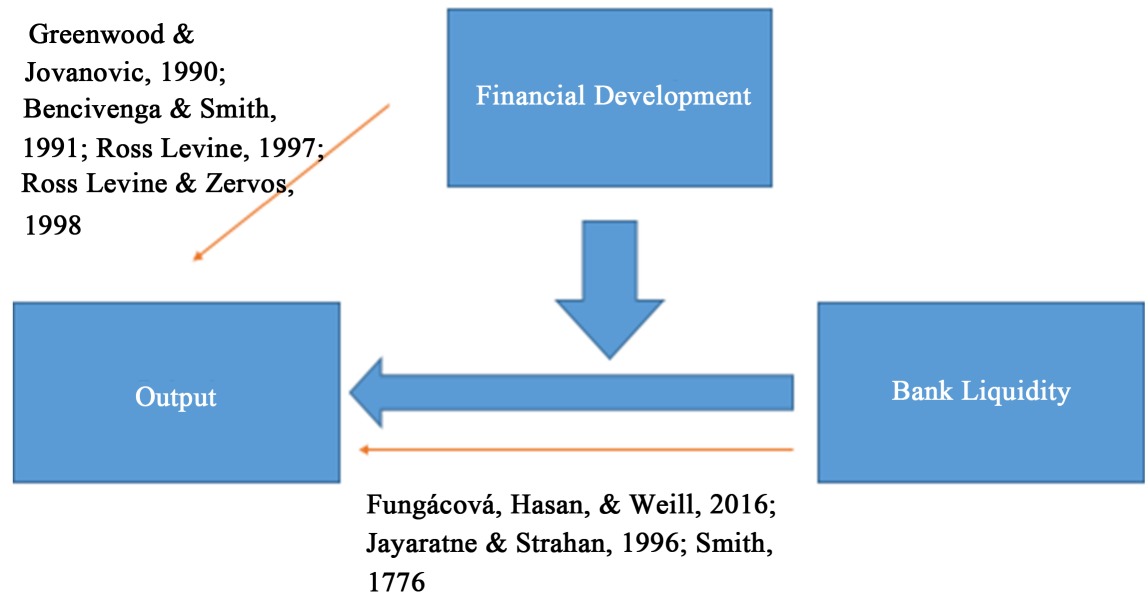

Figure 2. Diagram for Hypothesis 3. The blue diagram refers to what we study while the orange lines with authors show what prior research has been done. We look at the effect of financial development on output viaank liquidity. We are interested in the interaction variable between financial development and bank liquidity. 
Hypothesis 3b: Financial development negatively affects the impact of bank liquidity on output.

\section{Data, Sample and Variable Definition}

Although we have only a few variables that we take into consideration, there are many data points which are not available for all countries. The final dataset consists of 1503 data points with 119 countries and 18 years from 1997-2014. The nonavailability of data causes an omitted variables problem. There is a sample selection bias because we had to drop the countries and years in which data was not available.

\subsection{Financial Development}

Over the years, different papers have used a different set of measures of financial development (See e.g. Levine [12], Arestis and Demetriades [34] and Beck, Demirgüç-Kuntand Levine [35]) among others. We propose to use the Financial Development and Structure Dataset which contains a range of financial indicators (31 indicators in total), from 1960-2014, that measure the size, activity, and efficiency of financial intermediaries and markets. This is available on the World Bank website and has been developed over the years (Beck, Demirgüç-Kuntand and Levine [35], Beck, Demirg-Kuntand Levine [36] and Cihak, Demirgüç-Kunt, Feyen and Levine [37]). As there are too many factors which are given in this database, we choose the three indicators chosen by Carranza, Galdon-Sanchez and Gomez-Biscarri [13], who perform a PCA (Principal Component Analysis) to identify the key components of financial development. They follow with the use of factor analysis to identify the variables to include in their regression. The three variables chosen by them are Bank deposits to GDP, Stock Market Capitalization to GDP, and Central Bank Assets to GDP. These three variables account for $89 \%$ of the variation in financial development. The three variables can be interpreted as level of the financial intermediaries sector, size and activity of the stock market and the size of the central bank in a country. The complete list of indicators is given in the appendix.

\subsection{Monetary Policy}

For monetary policy, we use the lending rate prevalent in the country. Lending rate was more widely available than central banks' repo rates.

The lending rate is taken as the short or medium term rate at which money is available to the private sector. This was taken from the World Development Indicators Database.

\subsection{Gross Domestic Product}

The GDP of various countries can be obtained from the World Bank Database of World Development Indicators.

\subsection{Bank Liquidity}

We take the bank liquid reserves to total bank asset ratio from the World Bank 
database. This data is available on a cross-country level for 2001-2015. ${ }^{1}$

\section{Model}

We want to conduct a cross-country analysis on as many countries as possible with the data that is available. The final model will contain data from 2001-2015. The following three are the regression equations for the above three hypothesis.

$$
\begin{gathered}
\Delta \mathrm{GDP}_{j, t}=x_{0}+x_{1} \Delta \mathrm{MP}_{j, t-1}(-1)+\sum \beta_{k} \mathrm{FD}_{k, j, t-1} * \Delta \mathrm{MP}_{j, t-1}(-1)+\varepsilon_{j, t} \\
\Delta \mathrm{BL}_{j, t}=x_{0}+x_{1} \Delta \mathrm{MP}_{j, t-1}(-1)+\sum \beta_{k} \mathrm{FD}_{k, j, t-1} * \Delta \mathrm{MP}_{j, t-1}(-1)+\varepsilon_{j, t} \\
\Delta \mathrm{GDP}_{j, t}=x_{0}+x_{1} \Delta \mathrm{BL}_{j, t-1}+\sum \beta_{k} \mathrm{FD}_{k, j, t-1} * \Delta \mathrm{BL}_{i, j, t-1}+\varepsilon_{j, t}
\end{gathered}
$$

Here $\mathrm{BL}$ is the bank liquidity; MP refers to the monetary policy variable. FD is the variable for financial development. As there are multiple variables which are there for financial development we have generically named the variable $\mathrm{FD}_{k}$ where $k$ refers to the different variables used to calculate the financial development. Here, $j$ refers to the country and $t$ refers to the time period. GDP refers to the Gross Domestic Product of a specific country.

The change in MP variable is multiplied by -1 because a loosening in monetary policy is seen as a cut in interest rates. Hence to make the regressions easier to understand we multiply the MP variable by a minus sign. The FD variables that we use in the equation will be decided on the basis of a PCA that is conducted on all the variables that are available to measure financial development. Previous studies have shown that the size and depth of financial intermediaries and relative size of the central bank are usually used as measures of financial development (Carranza, Galdon-Sanchezand Gomez-Biscarri [13]). We follow the literature and use the same variables used in earlier papers.

In all of the three equations, we want to specifically look at the interaction term that we have posited, as we are mainly interested in the effect of financial development. The interaction term is meant to capture the extra effect of financial development while controlling for other variables. For example, a positive coefficient for the interaction term in equation 1 would suggest that with financial development the effect of monetary policy on output is stronger. In the all the equations depending on what the sign of the interaction term is, we have two underlying theories that can be true. A positive interaction term supports hypothesis 1a while a negative interaction term lends support to $1 \mathrm{~b}$.

\section{Main Empirical Analysis}

For the empirical analysis, we run regression on all the three equation mentioned above. In every place where we use the financial development indicator we use the three different variables that we have chosen to financial development and run the regressions. The three variables which are used as measures of financial development are i) Bank deposits to GDP, ii) Stock Market Capitalization to GDP, and iii) Central Bank Assets to GDP. To obtain better results, we also include year-wise dummies in all of our equations.

Source: http://data.worldbank.org/indicator/FD.RES.LIQU.AS.ZS, 28 Feb., 2017. 


\subsection{How Financial Development Affects the Impact of Monetary Policy on Output}

When we see the results of the regressions, we see that the interaction term between financial development and monetary policy is negative in all cases, regardless of which financial development indicator is taken into consideration, and mostly significant (two out of three). These values are also seen to be significant as seen in Table 1 . This supports our hypothesis that countries which better financial development propagate the monetary policy more effectively. This is because the economy and financial system in the country is fairly well structures and does not have too many leakages. Hence the monetary policy is more effective in countries with better levels of financial development.

A regression using Equation (1) has been run 3 times with the three different financial development indicators (Table 1). The coefficients in all cases are negative and very small (having e+07 and e+08) but are significant with $.1 \%$ for when the financial development variables are bank deposits to GDP and central bank assets to GDP.

As an example we can consider India and the US, out results show that monetary policy is more effectively transmitted in countries like the US compared to India and this similarly also has the rippling effect on output. The reason behind this is high levels of financial inclusion and a well-structured economic and financial system enables the policy makers to effectively control the transmission of monetary policy without there being leakages.

\subsection{How Financial Development Affects the Impact of Monetary Policy on Bank Liquidity}

In this case we see that the results are mostly positive and significant while one of the financial development indicators (Central bank assets to GDP) shows the opposing sign. As the results in this case as seen in Table 2, do not clearly tell us one side of the story we can say in most cases, our hypothesis that people in more financially developed countries are more prone to borrowing and putting money back into the banking system stands. This increases the liquidity in the banking system due to the multiplier effect. Our test of the second hypothesis using Equation (2) does not consistently show the same result when all financial development indicators are used (Table 2). The results are positive with $0.1 \%$ and 5\% significance in the case of bank deposits to GDP and Stock Market Capitalization to GDP. When the ratio of central bank assets to GDP is used in the equation, the regression yields a negative value for the interaction variable which is also significant.

To understand this better, let us again use the examples of the US and India. Our results show that in the US, more people are likely to use the banking system. Persons there also trust the banks to safeguard their deposits and provide them with a source of funds in case they need loans. Hence people in the US both deposit and withdraw from the banking system more as compared to India, where people might not put their money back into banks as a deposit, but instead keep it as cash. 
Table 1. Effect of financial development on the impact of monetary policy on output. 1a, $1 \mathrm{~b}$ and $1 \mathrm{c}$ use three different variables for financial development: Bank deposits to GDP, Stock Market Capitalization to GDP, and Central Bank Assets to GDP. (GDP = MP + $\mathrm{FD}^{\star} \mathrm{MP}+$ Year Dummies) (a) FD = Bank deposits to GDP; (b) FD = Stock Market Capitalization to GDP; (c) FD = Central Bank Assets to GDP.

(a)

\begin{tabular}{|c|c|c|c|c|}
\hline & Estimate & Std. Error & $t$-value & $p$-value \\
\hline (Intercept) & $1.302 \mathrm{e}+11$ & $5.537 \mathrm{e}+11$ & 0.235 & 0.814 \\
\hline MP & $1.039 \mathrm{e}+10$ & $1.845 \mathrm{e}+09$ & 5.630 & $2.16 \mathrm{e}-08^{\star * * *}$ \\
\hline FD1MP & $-2.001 \mathrm{e}+08$ & $4.515 \mathrm{e}+07$ & -4.433 & $1.00 \mathrm{e}-05^{\star * * *}$ \\
\hline Year Dum1998 & $-9.388 \mathrm{e}+09$ & $7.821 \mathrm{e}+11$ & -0.012 & 0.990 \\
\hline Year Dum1999 & $-4.294 \mathrm{e}+10$ & $7.821 \mathrm{e}+11$ & -0.055 & 0.956 \\
\hline Year Dum2000 & $9.307 e+10$ & $6.386 \mathrm{e}+11$ & 0.146 & 0.884 \\
\hline Year Dum2001 & $5.082 \mathrm{e}+10$ & $5.557 \mathrm{e}+11$ & 0.091 & 0.927 \\
\hline Year Dum2002 & $3.952 \mathrm{e}+10$ & $5.556 \mathrm{e}+11$ & 0.071 & 0.943 \\
\hline Year Dum2003 & $4.150 \mathrm{e}+10$ & $5.556 \mathrm{e}+11$ & 0.075 & 0.940 \\
\hline Year Dum2004 & $5.044 \mathrm{e}+10$ & $5.556 \mathrm{e}+11$ & 0.091 & 0.928 \\
\hline Year Dum2005 & $5.086 \mathrm{e}+10$ & $5.554 \mathrm{e}+11$ & 0.092 & 0.927 \\
\hline Year Dum2006 & $5.021 \mathrm{e}+10$ & $5.555 e+11$ & 0.090 & 0.928 \\
\hline Year Dum2007 & $5.810 \mathrm{e}+10$ & $5.555 e+11$ & 0.105 & 0.917 \\
\hline Year Dum2008 & $8.345 e+10$ & $5.556 e+11$ & 0.150 & 0.881 \\
\hline Year Dum2009 & $5.395 e+10$ & $5.557 e+11$ & 0.097 & 0.923 \\
\hline Year Dum2010 & $8.273 e+10$ & $5.557 \mathrm{e}+11$ & 0.149 & 0.882 \\
\hline Year Dum2011 & $1.094 \mathrm{e}+11$ & $5.557 e+11$ & 0.197 & 0.844 \\
\hline Year Dum2012 & $1.133 \mathrm{e}+11$ & $5.557 \mathrm{e}+11$ & 0.204 & 0.838 \\
\hline Year Dum2013 & $1.047 \mathrm{e}+11$ & $5.557 \mathrm{e}+11$ & 0.188 & 0.851 \\
\hline Year Dum2014 & $9.682 \mathrm{e}+10$ & $5.558 \mathrm{e}+11$ & 0.174 & 0.862 \\
\hline
\end{tabular}

${ }^{* * * *}$ is $0.1 \%$ significant, ${ }^{* * *}$ is $1 \%$ significant, ${ }^{* *}$ is $5 \%$ significant and ${ }^{*}$ is $10 \%$ significant. Although represented as MP, the variable has been multiplied by -1 to make interpretation easier.

(b)

\begin{tabular}{ccccc}
\hline & Estimate & Std. Error & $t$-value & $p$-value \\
\hline Intercept) & $1.877 \mathrm{e}+11$ & $7.628 \mathrm{e}+11$ & 0.246 & 0.80570 \\
MP & $1.171 \mathrm{e}+10$ & $3.581 \mathrm{e}+09$ & 3.269 & $0.00113^{* * *}$ \\
FD2MP & $-6.063 \mathrm{e}+07$ & $3.683 \mathrm{e}+07$ & -1.646 & 0.10013 \\
Year Dum1998 & $3.726 \mathrm{e}+10$ & $1.075 \mathrm{e}+12$ & 0.035 & 0.97236 \\
Year Dum1999 & $-2.731 \mathrm{e}+10$ & $1.075 \mathrm{e}+12$ & -0.025 & 0.97974 \\
Year Dum2000 & $1.614 \mathrm{e}+11$ & $9.310 \mathrm{e}+11$ & 0.173 & 0.86240 \\
Year Dum2001 & $1.492 \mathrm{e}+11$ & $7.672 \mathrm{e}+11$ & 0.194 & 0.84590 \\
\hline
\end{tabular}




\section{Continued}

\begin{tabular}{ccccc}
\hline Year Dum2002 & $1.573 \mathrm{e}+11$ & $7.675 \mathrm{e}+11$ & 0.205 & 0.83762 \\
Year Dum2003 & $1.516 \mathrm{e}+11$ & $7.672 \mathrm{e}+11$ & 0.198 & 0.84337 \\
Year Dum2004 & $1.543 \mathrm{e}+11$ & $7.669 \mathrm{e}+11$ & 0.201 & 0.84059 \\
Year Dum2005 & $1.620 \mathrm{e}+11$ & $7.667 \mathrm{e}+11$ & 0.211 & 0.83270 \\
Year Dum2006 & $1.703 \mathrm{e}+11$ & $7.667 \mathrm{e}+11$ & 0.222 & 0.82424 \\
Year Dum2007 & $1.947 \mathrm{e}+11$ & $7.671 \mathrm{e}+11$ & 0.254 & 0.79969 \\
Year Dum2008 & $2.491 \mathrm{e}+11$ & $7.674 \mathrm{e}+11$ & 0.325 & 0.74560 \\
Year Dum2009 & $2.104 \mathrm{e}+11$ & $7.677 \mathrm{e}+11$ & 0.274 & 0.78413 \\
Year Dum2010 & $2.574 \mathrm{e}+11$ & $7.677 \mathrm{e}+11$ & 0.335 & 0.73753 \\
Year Dum2011 & $3.016 \mathrm{e}+11$ & $7.677 \mathrm{e}+11$ & 0.393 & 0.69452 \\
Year Dum2012 & $3.294 \mathrm{e}+11$ & $7.680 \mathrm{e}+11$ & 0.429 & 0.66807 \\
Year Dum2013 & $7.240 \mathrm{e}+11$ & $7.778 \mathrm{e}+11$ & 0.931 & 0.35225 \\
Year Dum2014 & $7.033 \mathrm{e}+11$ & $7.778 \mathrm{e}+11$ & 0.904 & 0.36619 \\
\hline
\end{tabular}

${ }^{* * * *}$ is $0.1 \%$ significant, ${ }^{* * *}$ is $1 \%$ significant, ${ }^{* *}$ is $5 \%$ significant and ${ }^{*}$ is $10 \%$ significant. Although represented as MP, the variable has been multiplied by -1 to make interpretation easier.

(c)

\begin{tabular}{ccccc}
\hline & Estimate & Std. Error & $t$-value & $p$-value \\
\hline (Intercept) & $1.769 \mathrm{e}+11$ & $5.590 \mathrm{e}+11$ & 0.316 & 0.751730 \\
MP & $9.954 \mathrm{e}+09$ & $1.977 \mathrm{e}+09$ & 5.034 & $5.42 \mathrm{e}-07^{* * * *}$ \\
FD3MP & $-3.215 \mathrm{e}+08$ & $9.124 \mathrm{e}+07$ & -3.524 & $0.000439^{* * * *}$ \\
Year Dum1998 & $2.170 \mathrm{e}+10$ & $7.897 \mathrm{e}+11$ & 0.027 & 0.978088 \\
Year Dum1999 & $-2.965 \mathrm{e}+10$ & $7.897 \mathrm{e}+11$ & -0.038 & 0.970051 \\
Year Dum2000 & $6.278 \mathrm{e}+10$ & $6.448 \mathrm{e}+11$ & 0.097 & 0.922455 \\
Year Dum2001 & $4.773 \mathrm{e}+10$ & $5.612 \mathrm{e}+11$ & 0.085 & 0.932239 \\
Year Dum2002 & $4.244 \mathrm{e}+10$ & $5.611 \mathrm{e}+11$ & 0.076 & 0.939723 \\
Year Dum2003 & $4.490 \mathrm{e}+10$ & $5.612 \mathrm{e}+11$ & 0.080 & 0.936243 \\
Year Dum2004 & $5.642 \mathrm{e}+10$ & $5.612 \mathrm{e}+11$ & 0.101 & 0.919923 \\
Year Dum2005 & $5.796 \mathrm{e}+10$ & $5.610 \mathrm{e}+11$ & 0.103 & 0.917726 \\
Year Dum2006 & $6.303 \mathrm{e}+10$ & $5.610 \mathrm{e}+11$ & 0.112 & 0.910570 \\
Year Dum2007 & $8.132 \mathrm{e}+10$ & $5.611 \mathrm{e}+11$ & 0.145 & 0.884798 \\
Year Dum2008 & $1.151 \mathrm{e}+11$ & $5.613 \mathrm{e}+11$ & 0.205 & 0.837536 \\
Year Dum2009 & $8.910 \mathrm{e}+10$ & $5.613 \mathrm{e}+11$ & 0.159 & 0.873902 \\
Year Dum2010 & $1.096 \mathrm{e}+11$ & $5.614 \mathrm{e}+11$ & 0.195 & 0.845207 \\
Year Dum2011 & $1.345 \mathrm{e}+11$ & $5.614 \mathrm{e}+11$ & 0.240 & 0.810631 \\
Year Dum2012 & $1.360 \mathrm{e}+11$ & $5.613 \mathrm{e}+11$ & 0.242 & 0.808621 \\
Year Dum2013 & $1.253 \mathrm{e}+11$ & $5.613 \mathrm{e}+11$ & 0.223 & 0.823346 \\
Year Dum2014 & $1.145 \mathrm{e}+11$ & $5.614 \mathrm{e}+11$ & 0.204 & 0.838408 \\
\hline
\end{tabular}

$* * * *$ is $0.1 \%$ significant, ${ }^{* * *}$ is $1 \%$ significant, ${ }^{* *}$ is $5 \%$ significant and ${ }^{*}$ is $10 \%$ significant. Although represented as MP, the variable has been multiplied by -1 to make interpretation easier. 
Table 2. Effect of financial development on the impact of monetary policy on bank liquidity. 1a, 1b and 1c use three different variables for financial development: Bank deposits to GDP, Stock Market Capitalization to GDP, and Central Bank Assets to GDP. (BL = $\mathrm{MP}+\mathrm{FD}^{\star} \mathrm{MP}+$ Year Dummies) (a) FD = Bank deposits to GDP; (b) FD = Stock Market Capitalization to GDP; (c) FD = Central Bank Assets to GDP.

(a)

\begin{tabular}{|c|c|c|c|c|}
\hline & Estimate & Std. Error & $t$-value & $p$-value \\
\hline (Intercept) & 14.693638 & 20.994055 & 0.700 & 0.484 \\
\hline MP & -0.682413 & 0.069968 & -9.753 & $<2 \mathrm{e}-16^{* * * *}$ \\
\hline FD1MP & 0.011976 & 0.001712 & 6.996 & $4 \mathrm{e}-12^{* * * *}$ \\
\hline Year Dum1998 & -2.758622 & 29.653181 & -0.093 & 0.926 \\
\hline Year Dum1999 & 1.085730 & 29.651097 & 0.037 & 0.971 \\
\hline Year Dum 2000 & -9.181222 & 24.212952 & -0.379 & 0.705 \\
\hline Year Dum2001 & -2.061247 & 21.067697 & -0.098 & 0.922 \\
\hline Year Dum2002 & -0.508216 & 21.065257 & -0.024 & 0.981 \\
\hline Year Dum2003 & 1.686084 & 21.065808 & 0.080 & 0.936 \\
\hline Year Dum2004 & 2.821705 & 21.064096 & 0.134 & 0.893 \\
\hline Year Dum2005 & 2.875309 & 21.059206 & 0.137 & 0.891 \\
\hline Year Dum2006 & 3.800031 & 21.060139 & 0.180 & 0.857 \\
\hline Year Dum2007 & 5.238551 & 21.060838 & 0.249 & 0.804 \\
\hline Year Dum2008 & 2.806221 & 21.066961 & 0.133 & 0.894 \\
\hline Year Dum2009 & 4.509260 & 21.069014 & 0.214 & 0.831 \\
\hline Year Dum2010 & 5.820904 & 21.069467 & 0.276 & 0.782 \\
\hline Year Dum2011 & 5.712881 & 21.070673 & 0.271 & 0.786 \\
\hline Year Dum2012 & 6.180333 & 21.069708 & 0.293 & 0.769 \\
\hline Year Dum2013 & 6.309049 & 21.070122 & 0.299 & 0.765 \\
\hline Year Dum2014 & 6.564768 & 21.074571 & 0.312 & 0.755 \\
\hline
\end{tabular}

${ }^{* * * *}$ is $0.1 \%$ significant, ${ }^{* * *}$ is $1 \%$ significant, ${ }^{* *}$ is $5 \%$ significant and ${ }^{*}$ is $10 \%$ significant; Although represented as MP, the variable has been multiplied by -1 to make interpretation easier.

(b)

\begin{tabular}{ccccc}
\hline & Estimate & Std. Error & $t$-value & $p$-value \\
\hline Intercept $)$ & 11.1258703 & 13.3477203 & 0.834 & 0.4048 \\
MP & -0.5911167 & 0.0626627 & -9.433 & $<2 \mathrm{e}-16^{* * * *}$ \\
FD2MP & 0.0014735 & 0.0006445 & 2.287 & $0.0225^{\star *}$ \\
Year Dum1998 & -5.2104091 & 18.8082399 & -0.277 & 0.7818 \\
Year Dum1999 & 0.2780626 & 18.8076466 & 0.015 & 0.9882 \\
Year Dum2000 & -3.0910541 & 16.2921163 & -0.190 & 0.8496 \\
Year Dum2001 & -5.9602165 & 13.4253249 & -0.444 & 0.6572 \\
\hline
\end{tabular}




\section{Continued}

\begin{tabular}{ccccc}
\hline Year Dum2002 & -5.2956703 & 13.4301746 & -0.394 & 0.6935 \\
Year Dum2003 & -3.3959446 & 13.4245577 & -0.253 & 0.8004 \\
Year Dum2004 & -3.3144067 & 13.4195259 & -0.247 & 0.8050 \\
Year Dum2005 & -2.5683409 & 13.4161778 & -0.191 & 0.8482 \\
Year Dum2006 & 1.2768983 & 13.4164901 & 0.095 & 0.9242 \\
Year Dum2007 & 0.3612559 & 13.4241424 & 0.027 & 0.9785 \\
Year Dum2008 & -2.3206904 & 13.4279689 & -0.173 & 0.8628 \\
Year Dum2009 & 0.1882256 & 13.4333917 & 0.014 & 0.9888 \\
Year Dum2010 & 1.8006886 & 13.4344737 & 0.134 & 0.8934 \\
Year Dum2011 & 1.5254268 & 13.4332813 & 0.114 & 0.9096 \\
Year Dum2012 & 1.0363807 & 13.4386037 & 0.077 & 0.9386 \\
Year Dum2013 & 0.1676195 & 13.6104113 & 0.012 & 0.9902 \\
Year Dum2014 & 0.4432633 & 13.6108609 & 0.033 & 0.9740 \\
\hline
\end{tabular}

${ }^{* * * *}$ is $0.1 \%$ significant, ${ }^{* * *}$ is $1 \%$ significant, ${ }^{* *}$ is $5 \%$ significant and ${ }^{*}$ is $10 \%$ significant; Although represented as MP, the variable has been multiplied by -1 to make interpretation easier.

(c)

\begin{tabular}{|c|c|c|c|c|}
\hline & Estimate & Std. Error & $t$-value & $p$-value \\
\hline (Intercept) & 11.401158 & 21.603693 & 0.528 & 0.597763 \\
\hline MP & -0.307833 & 0.076411 & -4.029 & $5.91 \mathrm{e}-05^{\star * * *}$ \\
\hline FD3MP & -0.011713 & 0.003526 & -3.322 & $0.000917^{\star * * *}$ \\
\hline Year Dum 1998 & -4.942802 & 30.520031 & -0.162 & 0.871366 \\
\hline Year Dum1999 & 0.238679 & 30.519266 & 0.008 & 0.993761 \\
\hline Year Dum2000 & -5.903518 & 24.919537 & -0.237 & 0.812766 \\
\hline Year Dum2001 & -0.360159 & 21.687339 & -0.017 & 0.986753 \\
\hline Year Dum2002 & 0.620376 & 21.685844 & 0.029 & 0.977182 \\
\hline Year Dum2003 & 3.027581 & 21.686402 & 0.140 & 0.888990 \\
\hline Year Dum2004 & 4.883863 & 21.685940 & 0.225 & 0.821850 \\
\hline Year Dum2005 & 5.070615 & 21.680127 & 0.234 & 0.815110 \\
\hline Year Dum2006 & 6.009745 & 21.681836 & 0.277 & 0.781684 \\
\hline Year Dum2007 & 6.831276 & 21.685114 & 0.315 & 0.752792 \\
\hline Year Dum2008 & 4.543812 & 21.692447 & 0.209 & 0.834116 \\
\hline Year Dum2009 & 5.850741 & 21.693281 & 0.270 & 0.787429 \\
\hline Year Dum 2010 & 7.615429 & 21.694493 & 0.351 & 0.725618 \\
\hline Year Dum2011 & 7.309172 & 21.695708 & 0.337 & 0.736247 \\
\hline Year Dum2012 & 7.960987 & 21.693432 & 0.367 & 0.713692 \\
\hline Year Dum2013 & 8.017793 & 21.693602 & 0.370 & 0.711742 \\
\hline Year Dum2014 & 8.980942 & 21.696971 & 0.414 & 0.678992 \\
\hline
\end{tabular}

$* * * *$ is $0.1 \%$ significant, ${ }^{* * *}$ is $1 \%$ significant, ${ }^{* *}$ is $5 \%$ significant and ${ }^{*}$ is $10 \%$ significant; Although represented as MP, the variable has been multiplied by -1 to make interpretation easier. 


\subsection{How Financial Development Affects the Impact of Bank Liquidity on Output}

Here when we look at how financial development affects the impact of bank liquidity on output. The regressions results support our hypothesis that persons in more developed countries tend to trust banks more and hence seem to want to put their money in banks. They are also likelier to borrow money from banks and product more output for every rupee that they have borrowed. The results in Table 3 show that for all of the three different measures of financial development, we see that interaction between financial development and bank liquidity is positive and significant in two out of three cases.

The results of regression 3 show that the interaction variable between bank liquidity and each of the financial development variables is positive (Table 3 ). The value is also significant for the financial development variables, bank deposits to GDP and central bank assets to GDP at $0.1 \%$ and $10 \%$ respectively.

Taking the US and India as representative of a financially developed and not so financially developed country respectively, our results suggest that there are less cash leakages in the US compared to India, as the level of financial development is better there. In comparison to India, when loanable funds are made available in the US, more people are likely to borrow that money and produce output from it. In India on the other hand, people may not prefer to borrow from banks as they lack a certain trust in the banking system.

\subsection{Summary of Results}

Table 4 summarizes the results of all empirical tests. The three different financial development variables used are column headings and the rows represent the regression equations that are run. The values given in brackets refer to the levels of significance.

\section{Conclusions}

The paper has examined how different levels of financial development affect bank liquidity and output. Previous literature has documented opposing effects of financial development. Our paper combines various strands of literature to develop three bidirectional hypotheses on the effect of financial development on bank liquidity and output as measured by GDP. The contribution of this paper is a more definitive analysis by looking at the development across 119 countries.

First we find support for the hypothesis that financial development impedes the impact of monetary policy on output. Our results conclusively show that monetary policy is more effectively transmitted in countries that are more financially developed. We also find that the impact of monetary policy is less in poorer countries, perhaps owing to a lower number of financial intermediaries available to aid in the transmission of monetary policy. Second, we show that financial development positively affects the impact of monetary policy on bank liquidity. Previous literature has attributed this finding to the fact that countries which are more financially advanced tend to use the banking system more. Due 
Table 3. Effect of financial development on the impact of bank liquidity on output. 1a, 1b and $1 \mathrm{c}$ use three different variables for financial development: Bank deposits to GDP, Stock Market Capitalization to GDP, and Central Bank Assets to GDP. (GDP = BL + $\mathrm{FD}^{\star B L}+$ Year Dummies) (a) FD = Bank deposits to GDP; (b) FD = Stock Market Capitalization to GDP; (c) FD = Central Bank Assets to GDP.

(a)

\begin{tabular}{|c|c|c|c|c|}
\hline & Estimate & Std. Error & $t$-value & $p$-value \\
\hline (Intercept) & $1.084 \mathrm{e}+11$ & $5.523 e+11$ & 0.196 & 0.844 \\
\hline $\mathrm{BL}$ & $-5.749 e+09$ & $9.043 e+08$ & -6.358 & $2.74 \mathrm{e}-10^{* * * *}$ \\
\hline FD1BL & $1.185 \mathrm{e}+08$ & $2.725 \mathrm{e}+07$ & 4.350 & $1.46 \mathrm{e}-05^{* * * *}$ \\
\hline Year Dum1998 & $-1.636 e+10$ & $7.809 e+11$ & -0.021 & 0.983 \\
\hline Year Dum1999 & $-3.083 e+10$ & $7.809 e+11$ & -0.039 & 0.969 \\
\hline Year Dum 2000 & $3.786 e+10$ & $6.376 \mathrm{e}+11$ & 0.059 & 0.953 \\
\hline Year Dum2001 & $2.641 \mathrm{e}+10$ & $5.548 \mathrm{e}+11$ & 0.048 & 0.962 \\
\hline Year Dum2002 & $2.296 \mathrm{e}+10$ & $5.548 \mathrm{e}+11$ & 0.041 & 0.967 \\
\hline Year Dum2003 & $3.872 \mathrm{e}+10$ & $5.548 \mathrm{e}+11$ & 0.070 & 0.944 \\
\hline Year Dum2004 & $5.703 e+10$ & $5.547 \mathrm{e}+11$ & 0.103 & 0.918 \\
\hline Year Dum2005 & $6.779 e+10$ & $5.546 \mathrm{e}+11$ & 0.122 & 0.903 \\
\hline Year Dum2006 & $7.198 \mathrm{e}+10$ & $5.546 e+11$ & 0.130 & 0.897 \\
\hline Year Dum2007 & $8.386 e+10$ & $5.547 \mathrm{e}+11$ & 0.151 & 0.880 \\
\hline Year Dum2008 & $1.001 \mathrm{e}+11$ & $5.548 \mathrm{e}+11$ & 0.180 & 0.857 \\
\hline Year Dum2009 & $6.922 \mathrm{e}+10$ & $5.549 \mathrm{e}+11$ & 0.125 & 0.901 \\
\hline Year Dum2010 & $1.011 \mathrm{e}+11$ & $5.549 \mathrm{e}+11$ & 0.182 & 0.855 \\
\hline Year Dum2011 & $1.300 \mathrm{e}+11$ & $5.549 \mathrm{e}+11$ & 0.234 & 0.815 \\
\hline Year Dum2012 & $1.339 \mathrm{e}+11$ & $5.549 \mathrm{e}+11$ & 0.241 & 0.809 \\
\hline Year Dum2013 & $1.217 \mathrm{e}+11$ & $5.549 e+11$ & 0.219 & 0.826 \\
\hline Year Dum2014 & $1.157 \mathrm{e}+11$ & $5.550 \mathrm{e}+11$ & 0.209 & 0.835 \\
\hline
\end{tabular}

${ }^{* * * *}$ is $0.1 \%$ significant, ${ }^{* * *}$ is $1 \%$ significant, ${ }^{* *}$ is $5 \%$ significant and ${ }^{*}$ is $10 \%$ significant.

(b)

\begin{tabular}{ccccc}
\hline & Estimate & Std. Error & $t$-value & $p$-value \\
\hline Intercept) & $2.250 \mathrm{e}+11$ & $7.552 \mathrm{e}+11$ & 0.298 & 0.766 \\
BL & $-1.088 \mathrm{e}+10$ & $2.338 \mathrm{e}+09$ & -4.655 & $3.87 \mathrm{e}-06^{* * * *}$ \\
FD2BL & $3.859 \mathrm{e}+07$ & $2.809 \mathrm{e}+07$ & 1.374 & 0.170 \\
Year Dum1998 & $-2.008 \mathrm{e}+10$ & $1.066 \mathrm{e}+12$ & -0.019 & 0.985 \\
Year Dum1999 & $-1.559 \mathrm{e}+10$ & $1.066 \mathrm{e}+12$ & -0.015 & 0.988 \\
Year Dum2000 & $1.113 \mathrm{e}+11$ & $9.236 \mathrm{e}+11$ & 0.121 & 0.904 \\
Year Dum2001 & $8.919 \mathrm{e}+10$ & $7.612 \mathrm{e}+11$ & 0.117 & 0.907 \\
Year Dum2002 & $1.015 \mathrm{e}+11$ & $7.613 \mathrm{e}+11$ & 0.133 & 0.894 \\
\hline
\end{tabular}




\section{Continued}

\begin{tabular}{lllll}
\hline Year Dum2003 & $1.220 \mathrm{e}+11$ & $7.610 \mathrm{e}+11$ & 0.160 & 0.873 \\
Year Dum2004 & $1.310 \mathrm{e}+11$ & $7.607 \mathrm{e}+11$ & 0.172 & 0.863 \\
Year Dum2005 & $1.507 \mathrm{e}+11$ & $7.606 \mathrm{e}+11$ & 0.198 & 0.843 \\
Year Dum2006 & $1.966 \mathrm{e}+11$ & $7.606 \mathrm{e}+11$ & 0.258 & 0.796 \\
Year Dum2007 & $2.117 \mathrm{e}+11$ & $7.609 \mathrm{e}+11$ & 0.278 & 0.781 \\
Year Dum2008 & $2.387 \mathrm{e}+11$ & $7.612 \mathrm{e}+11$ & 0.314 & 0.754 \\
Year Dum2009 & $2.211 \mathrm{e}+11$ & $7.613 \mathrm{e}+11$ & 0.290 & 0.772 \\
Year Dum2010 & $2.877 \mathrm{e}+11$ & $7.613 \mathrm{e}+11$ & 0.378 & 0.706 \\
Year Dum2011 & $3.308 \mathrm{e}+11$ & $7.613 \mathrm{e}+11$ & 0.435 & 0.664 \\
Year Dum2012 & $3.550 \mathrm{e}+11$ & $7.616 \mathrm{e}+11$ & 0.466 & 0.641 \\
Year Dum2013 & $7.541 \mathrm{e}+11$ & $7.711 \mathrm{e}+11$ & 0.978 & 0.328 \\
Year Dum2014 & $7.375 \mathrm{e}+11$ & $7.711 \mathrm{e}+11$ & 0.956 & 0.339 \\
\hline
\end{tabular}

${ }^{* * * *}$ is $0.1 \%$ significant, ${ }^{* * *}$ is $1 \%$ significant, ${ }^{* *}$ is $5 \%$ significant and ${ }^{*}$ is $10 \%$ significant.

(c)

\begin{tabular}{|c|c|c|c|c|}
\hline & Estimate & Std. Error & $t$-value & $p$-value \\
\hline (Intercept) & $1.342 \mathrm{e}+11$ & $5.592 \mathrm{e}+11$ & 0.240 & 0.8104 \\
\hline $\mathrm{BL}$ & $-3.617 e+09$ & $7.563 e+08$ & -4.782 & $1.92 \mathrm{e}-06^{* * * *}$ \\
\hline FD3BL & $6.802 \mathrm{e}+07$ & $3.926 \mathrm{e}+07$ & 1.733 & $0.0834^{\star}$ \\
\hline Year Dum1998 & $-1.165 e+10$ & $7.906 \mathrm{e}+11$ & -0.015 & 0.9882 \\
\hline Year Dum1999 & $-1.327 e+10$ & $7.906 \mathrm{e}+11$ & -0.017 & 0.9866 \\
\hline Year Dum2000 & $1.815 \mathrm{e}+10$ & $6.455 e+11$ & 0.028 & 0.9776 \\
\hline Year Dum2001 & $1.147 \mathrm{e}+10$ & $5.618 \mathrm{e}+11$ & 0.020 & 0.9837 \\
\hline Year Dum2002 & $1.344 \mathrm{e}+10$ & $5.618 \mathrm{e}+11$ & 0.024 & 0.9809 \\
\hline Year Dum2003 & $3.141 \mathrm{e}+10$ & $5.618 \mathrm{e}+11$ & 0.056 & 0.9554 \\
\hline Year Dum2004 & $5.043 e+10$ & $5.618 \mathrm{e}+11$ & 0.090 & 0.9285 \\
\hline Year Dum2005 & $5.599 \mathrm{e}+10$ & $5.616 e+11$ & 0.100 & 0.9206 \\
\hline Year Dum2006 & $6.721 \mathrm{e}+10$ & $5.616 \mathrm{e}+11$ & 0.120 & 0.9048 \\
\hline Year Dum2007 & $8.656 e+10$ & $5.617 e+11$ & 0.154 & 0.8776 \\
\hline Year Dum2008 & $1.115 \mathrm{e}+11$ & $5.619 e+11$ & 0.198 & 0.8428 \\
\hline Year Dum2009 & $9.259 \mathrm{e}+10$ & $5.619 e+11$ & 0.165 & 0.8692 \\
\hline Year Dum2010 & $1.238 \mathrm{e}+11$ & $5.620 \mathrm{e}+11$ & 0.220 & 0.8257 \\
\hline Year Dum2011 & $1.503 e+11$ & $5.620 \mathrm{e}+11$ & 0.267 & 0.7891 \\
\hline Year Dum2012 & $1.540 \mathrm{e}+11$ & $5.619 e+11$ & 0.274 & 0.7841 \\
\hline Year Dum2013 & $1.478 \mathrm{e}+11$ & $5.619 e+11$ & 0.263 & 0.7926 \\
\hline Year Dum2014 & $1.417 \mathrm{e}+11$ & $5.620 \mathrm{e}+11$ & 0.252 & 0.8010 \\
\hline
\end{tabular}

${ }^{* * *}$ is $0.1 \%$ significant, ${ }^{* * *}$ is $1 \%$ significant, ${ }^{* *}$ is $5 \%$ significant and ${ }^{*}$ is $10 \%$ significant. 
Table 4. Summary of regressions.

\begin{tabular}{lccc}
\hline & $\begin{array}{c}\text { Bank deposits } \\
\text { to GDP }\end{array}$ & $\begin{array}{c}\text { Stock Market } \\
\text { Capitalization to GDP }\end{array}$ & $\begin{array}{c}\text { Central Bank } \\
\text { Assets to GDP }\end{array}$ \\
\hline Equation (1) & Negative (0.1\%) & Negative & Negative (0.1\%) \\
Equation (2) & Positive (0.1\%) & Positive (5\%) & Negative (0.1\%) \\
Equation (3) & Positive (0.1\%) & Positive & Positive (10\%) \\
\hline
\end{tabular}

to this greater use, the multiplier effect is more powerful and more liquidity is created in the entire system when there is monetary policy loosening.

Finally, we show that financial development negatively affects the impact of bank liquidity on output. The finding goes to show the importance of good governance and faith in the banking system. Our results show that people in less financially developed countries tend to trust the banking system less and hence do not produce high levels of output compared to developed nations when provided with an infusion of bank liquidity. Consider that 10 crores worth of loans suddenly became available to banks both in the US and India. We believe that the 10 crores worth of loans will produce more GDP output in the US because borrowers trust the banks more there and are more likely to borrow loanable funds and have less cash leakages than in India. Also as the levels of financial inclusion in the US are much greater, a borrower in India may not even have proper access to the loans given by the bank. Hence in the US, there will be more people who will borrow from the banks and create output from it.

\section{Further Research}

An upcoming area of research is the impact of market integration on various traditionally held banking theories. Market integration refers to the integration of markets of several countries. The classic example is the European Union. There are many different countries which comprise the European Union, and all the countries do not have the same level of financial development, either in terms of active stock markets or in the presence of other secondary markets. Despite this being the case, as their markets are integrated, the banking systems in all countries function in tandem. This model is worth studying for the ASEAN countries.

\section{Acknowledgements}

The authors are grateful to Harshal Rajan Mulay and Pulkit Taluja for their valuable inputs and feedback on the paper and to the Indian Institute of Management Calcutta for a Research Project Grant (RP 3690) for financial support.

\section{References}

[1] Leland, H.E. and Pyle, D.H. (1977) Informational Asymmetries, Financial Structure, and Financial Intermediation. Journal of Finance, 32, 371-387. https://doi.org/10.2307/2326770

[2] Diamond, D.W. (1984) Financial Intermediation and Delegated Monitoring. The 
Review of Economic Studies, 51, 393-414. https://doi.org/10.2307/2297430

[3] Ramakrishnan, R.T.S. and Thakor, A.V. (1984) Information Reliability and a Theory of Financial Intermediation. The Review of Economic Studies, 51, 415-432. https://doi.org/10.2307/2297431

[4] Berger, A.N. and Bouwman, C.H.S. (2009) Bank Liquidity Creation. Review of Financial Studies, 22, 3779-3837. https://doi.org/10.1093/rfs/hhn104

[5] Bryant, J. (1980) A Model of Reserves, Bank Runs, and Deposit Insurance. Journal of Banking and Finance, 4, 335-344. https://doi.org/10.1016/0378-4266(80)90012-6

[6] Diamond, D.W. and Dybvig, P.H. (1983) Bank Runs, Deposit Insurance, and Liquidity. Journal of Political Economy, 91, 401-419. https://doi.org/10.1086/261155

[7] Diamond, D.W. (2007) Banks and Liquidity Creation: A Simple Exposition of the Diamond-Dybvig Model. Economic Quarterly, 93, 189-200.

[8] Kashyap, A.K., Rajan, R. and Stein, J.C. (2002) Banks as Liquidity Providers: An Explanation for the Coexistence of Lending and Deposit-Taking. Journal of Finance, 57, 33-73. https://doi.org/10.1111/1540-6261.00415

[9] Holmstrom, B. and Tirole, J. (1998) Private and Public Supply of Liquidity. Journal of Political Economy, 106, 1-40. https://doi.org/10.1086/250001

[10] Friedman, M. (1968) The Role of Monetary Policy. The American Economic Review, 58, 269-295.

[11] Demirgüç-Kunt, A. and Levine, R. (2008) Finance, Financial Sector Policies, and Long-Run Growth. The World Bank Development Research Group.

https://doi.org/10.1596/1813-9450-4469

[12] Levine, R. (2005) Chap. 12. Finance and Growth: Theory and Evidence. In: Aghion, P. and Durlauf, S.N., Eds., Handbook of Economic Growth, Vol. 1, Part A, Elsevier, Amsterdam, 865-934. https://doi.org/10.1016/S1574-0684(05)01012-9

[13] Carranza, L., Galdon-Sanchez, J.E. and Gomez-Biscarri, J. (2010) Understanding the Relationship between Financial Development and Monetary Policy. Review of International Economics, 18, 849-864. https://doi.org/10.1111/j.1467-9396.2010.00926.x

[14] Sims, C.A. (1992) Interpreting the Macroeconomic Time Series Facts. The Effects of Monetary Policy. European Economic Review, 36, 975-1000. https://doi.org/10.1016/0014-2921(92)90041-t

[15] Uhlig, H. (2005) What Are the Effects of Monetary Policy on Output? Results from an Agnostic Identification Procedure. Journal of Monetary Economics, 52, 381-419. https://doi.org/10.1016/j.jmoneco.2004.05.007

[16] Bernanke, B.S. and Gertler, M. (1995) Inside the Black Box: The Credit Channel of Monetary Policy Transmission. Journal of Economic Perspectives, 9, 27-48.

[17] Kashyap, A. and Stein, J. (1997) What Do a Million Banks Have to Say about the Transmission of Monetary Policy? The American Economic Review, 90, 407-428.

[18] Bencivenga, V.R. and Smith, B.D. (1991) Financial Intermediation and Endogenous Growth. Review of Economic Studies, 58, 195-209. https://doi.org/10.2307/2297964

[19] Greenwood, J. and Jovanovic, B. (1990) Financial Development, Growth, and the Distribution of Income. Journal of Political Economy, 98, 1076-1107. https://doi.org/10.1086/261720

[20] Jayaratne, J. and Strahan, P.E. (1996) The Finance-Growth Nexus: Evidence from Bank Branch Deregulation. The Quarterly Journal of Economics, 111, 639-670. https://doi.org/10.2307/2946668

[21] Smith, A. (1776) An Inquiry into the Nature and Causes of the Wealth of Nations. 
Ch. 1-2, 1000.

[22] Fungácová, Z., Hasan, I. and Weill, L. (2016) Trust in Banks. BOFIT Discussion Paper No. 7/2016, Gabelli School of Business, Fordham University Research Paper No. 2782358. https://ssrn.com/abstract $=2782358$

[23] Berger, A.N. and Bouwman, C.H.S. (2012) Bank Liquidity Creation, Monetary Policy, and Financial Crises.

[24] Bernanke, B. and Blinder, A. (1992) The Federal Funds Rate and the Channels of Monetary Transmission. American Economic Review, 82, 901-921.

[25] Stein, J.C. (1998) An Adverse-Selection Model of Bank Asset and Liability Management with Implications for the Transmission of Monetary Policy. The RAND Journal of Economics, 29, 466.

[26] Stiglitz, J.E. and Weiss, A. (1981) Credit Rationing in Markets with Rationing Credit Information Imperfect. The American Economic Review, 71, 393-410.

[27] Levine, R. and Zervos, S. (1998) Stock Markets, Banks, and Economic Growth. American Economic Review, 88, 537-558.

[28] Levine, R. (1997) Financial Development and Economic Growth: Views and Agenda. Journal of Economic Literature, 35, 688-726.

[29] Wu, M. and Ni, Y. (2014) Reinvestigating the Effect of Money on Output for Taiwan with Additional Robustness. Theoretical Economics Letters, 4, 350-361. https://doi.org/10.4236/tel.2014.45046

[30] Berger, A.N. and Sedunov, J. (2017) Bank Liquidity Creation and Real Economic Output. Journal of Banking \& Finance, 81, 1-19.

[31] Stulz, R.M. (2003) Risk Management and Derivatives. Southwestern College Publishing, Cincinnati, $\mathrm{OH}$.

[32] Kashyap, A.K. and Stein, J.C. (2000) What Do a Million Observations on Banks Say about the Transmission of Monetary Policy? American Economic Review, 90, 407428.

[33] Keho, Y. (2016) Non-Linear Effect of Remittances on Banking Sector Development: Panel Evidence from Developing Countries. Theoretical Economics Letters, 6, 10961104. https://doi.org/10.4236/tel.2016.65105

[34] Arestis, P. and Demetriades, P. (1997) Financial Development and Economic Growth: Assessing the Evidence. The Economic Journal, 107, 783-799. https://doi.org/10.1111/j.1468-0297.1997.tb00043.x

[35] Beck, T., Demirgüç-Kunt, A. and Levine, R. (2000) A New Database on the Structure and Development of the Financial Sector. The World Bank Economic Review, 14, 597-605. https://doi.org/10.1093/wber/14.3.597

[36] Beck, T., Demirgüç-Kunt, A. and Levine, R. (2010) Financial Institutions and Markets across Countries and over Time: The Updated Financial Development and Structure Database. World Bank Economic Review, 24, 77-92. https://doi.org/10.1093/wber/lhp016

[37] Cihak, M., Demirgüç-Kunt, A., Feyen, E. and Levine, R. (2012) Benchmarking Financial Systems around the World. World Bank Policy Research Working Papers WPS6175, 1-58.

http://documents.worldbank.org/curated/en/2012/08/16669897/benchmarking-fina $\underline{\text { ncial-systems-around-world }}$ 
Submit or recommend next manuscript to SCIRP and we will provide best service for you:

Accepting pre-submission inquiries through Email, Facebook, LinkedIn, Twitter, etc. A wide selection of journals (inclusive of 9 subjects, more than 200 journals)

Providing 24-hour high-quality service

User-friendly online submission system

Fair and swift peer-review system

Efficient typesetting and proofreading procedure

Display of the result of downloads and visits, as well as the number of cited articles Maximum dissemination of your research work

Submit your manuscript at: http://papersubmission.scirp.org/

Or contact tel@scirp.org 